\title{
A!
}

This is an electronic reprint of the original article.

This reprint may differ from the original in pagination and typographic detail.

Kämpjärvi, Petteri; Jämsä-Jounela, Sirkka-Liisa

\section{Level control strategies for flotation cells}

Published in:

Minerals Engineering

DOI:

10.1016/j.mineng.2003.06.004

Published: 01/01/2003

Document Version

Peer reviewed version

Please cite the original version:

Kämpjärvi, P., \& Jämsä-Jounela, S-L. (2003). Level control strategies for flotation cells. Minerals Engineering, 16(11), 1061-1068. https://doi.org/10.1016/j.mineng.2003.06.004

This material is protected by copyright and other intellectual property rights, and duplication or sale of all or part of any of the repository collections is not permitted, except that material may be duplicated by you for your research use or educational purposes in electronic or print form. You must obtain permission for any other use. Electronic or print copies may not be offered, whether for sale or otherwise to anyone who is not an authorised user. 


\title{
LEVEL CONTROL STRATEGIES FOR FLOTATION CELLS
}

\author{
P. Kämpjärvi, S-L. Jämsä-Jounela \\ Helsinki University of Technology \\ Laboratory of Process Control and Automation \\ Kemistintie 1, 02150 Espoo, FINLAND \\ E-mail: sirkka-liisa.jamsa-jounela@aalto.fi
}

\begin{abstract}
Flotation is a difficult process to run efficiently. One way to make flotation performance better is to improve cell level control. However, controlling pulp levels in flotation cells is a complex control task because of strong interactions between the levels in flotation cells. Therefore advanced controllers are needed to give good level control. This paper deals with a model of six flotation cells in series. Simulations are performed to compare different control strategies. Four control strategies are considered: one SISO controller and three different MIMO controllers including a new multivariable controller. It is shown that level control performances of the MIMO controllers are significantly better than that of the classical SISO controller.
\end{abstract}

Keywords: Flotation machines; Froth flotation; Process control; Mineral processing

\section{Introduction}

Level control of flotation cells is a very complex task due to high interactions between the process variables. A control action implemented at any point in the flotation circuit tends to be transmitted to both upstream and downstream units, and sometimes with amplification. Large variations in the flow rate to the first cell and varying composition of the raw ore also cause problems.

Flotation cells are conventionally controlled by isolated PI-controllers. PI control works well when the cell being controlled is isolated. However, in a flotation circuit where interactions are strong, PI control does not meet the requirements of high control performance. Hence a considerable amount of research has been carried out over the last few years to develop better control techniques for flotation circuits (Jämsä-Jounela et al., 2001).

Niemi et al. (1974), Koivo and Cojocariu (1977) used a single cell model when developing an optimal control algorithm via applications of the maximum principle. Andersen et al. (1981) and Zargoza and Herbst (1987) reported an application of state feedback control and a Kalman filter for rougher flotation control. Hammoude and Smith (1981) used a linear model to develop a minimum-variance controller for recleaning. New advanced control method has been also recommended for the control of flotation processes by (Stenlund and Medvedev, 2000).

The aim of this research is to study and compare different control strategies from the point of view of cell level control. In addition, a new control strategy is presented and implemented. Its performance is compared to three different strategies: one traditional SISO control strategy, and two MIMO control strategies. The strategies are compared by the means of special performance indices.

In the following the mathematical model of a flotation cell is first developed and a five cells in series cell configuration is constructed. The simulations are then performed in order to determine suitable control parameters for controllers of the cell levels. Simulation was performed with Matlab 5.2.0 and its Simulink library. 


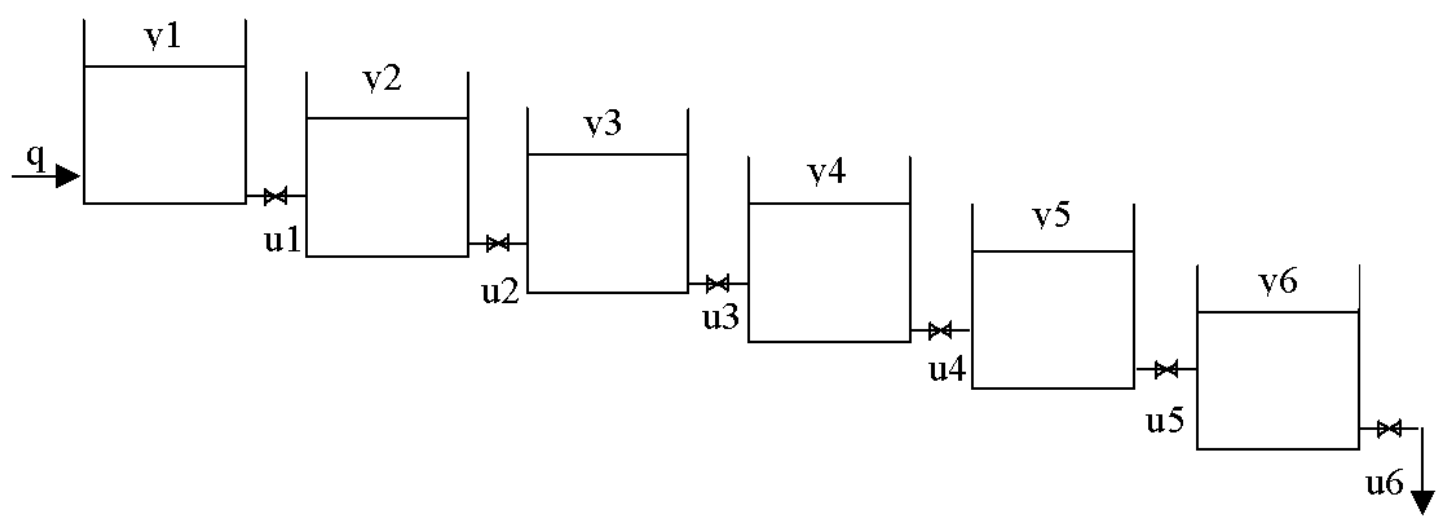

Fig. 1. Schematic diagram of flotation cells

\section{Mathematical modelling of flotation cells in series}

In the flotation process the pulp is fed into the first cell and the froth is collected in the launders. The feed can be measured by a flow measurement, and the remaining pulp flows into the next cell. The magnitude of the flow depends on the pressure difference between two adjacent cells, the position of control valves, and the viscosity and density of the pulp. The magnitude of the pressure difference can be determined from the physical height difference of the cells. The pulp level in a cell is measured and controlled by adjusting the control valve.

In the following a flotation cell is considered as a tank of perfectly mixed pulp. Since the pulp is perfectly mixed, the density is the same throughout the cell, i.e. there are no spatial density gradients in the cell. As the froth flow is small compared with the pulp flow, it is ignored in the outgoing flows. The impact of the air feed on the pulp level is also ignored.

The cells under study do not have the properties of ideal tanks because the cross-sectional area of the cell is not constant. A mathematical model for the physical properties will be developed and discussed next.

\subsection{Single cells in series}

In a flotation process several single cells are connected in series as shown in Fig. 1.

For the first cell in the series:

$\frac{\partial V_{1}}{\partial t}=\left(q-F_{1}\right)=q-K C_{v}\left(u_{1}\right) \sqrt{y_{1}-y_{2}+h_{1}}$

where $\mathrm{q}=$ feed rate to the first cell, $\mathrm{y}_{1}=$ pulp level in the first cell, $\mathrm{y}_{2}=$ pulp level in the second cell, $\mathrm{h}_{\mathrm{n}}$ $=$ physical difference in height between the cells, $\mathrm{u}_{1}$ $=$ control signal, $\mathrm{K}=$ constant coefficient, $\mathrm{F}_{1}=$ outflow from the first cell, and $\mathrm{C}_{\mathrm{v}}=$ valve coefficient.

The equations for cells 2, 3 and 4 are respectively (i $=2,3$ and 4)

$\frac{\partial V_{i}}{\partial t}=\left(F_{i-1}-F_{i}\right)=K C_{v}\left(u_{i-1}\right) \sqrt{y_{i-1}-y_{i}+h_{i-1}}$
$-K C_{v}\left(u_{i}\right) \sqrt{y_{i}-y_{i+1}+h_{i}}$

The equation for the last cell $(n=5)$

$$
\begin{aligned}
& \frac{\partial V_{n}}{\partial t}=\left(F_{n-1}-F_{n}\right)=K C_{v}\left(u_{n-1}\right) \sqrt{y_{n-1}-y_{n}+h_{n-1}} \\
& -K C_{v}\left(u_{n}\right) \sqrt{y_{n}+h_{n}}
\end{aligned}
$$

In the case of an ideal tank, the cross-section of a cell is assumed to be constant. The pulp levels in the cells can therefore be written as:

$$
\begin{aligned}
& \frac{\partial y_{1}}{\partial t}=\frac{\left(q-F_{1}\right)}{A_{1}}= \\
& \frac{q-K C_{v}\left(u_{1}\right) \sqrt{y_{1}-y_{2}+h_{1}}}{A_{1}} \\
& \frac{\partial y_{i}}{\partial t}=\frac{K_{i-1} C_{v}\left(u_{i-1}\right) \sqrt{y_{i-1}-y_{i}+h_{i-1}}}{A_{i}} \\
& -\frac{K C_{v}\left(u_{i}\right) \sqrt{y_{i}-y_{i+1}+h_{i}}}{A_{i}}
\end{aligned}
$$

where $\mathrm{i}=2,3$, and 4 .

$$
\begin{aligned}
& \frac{\partial y_{n}}{\partial t}=\frac{K C_{v}\left(u_{n-1}\right) \sqrt{y_{n-1}-y_{n}+h_{n-1}}}{A_{n}} \\
& -\frac{K C_{v}\left(u_{n}\right) \sqrt{y_{n}+h_{n}}}{A_{n}}
\end{aligned}
$$

where $n=5$. 


\subsection{Double cells in series}

Mathematical models for the double cells can be derived in a similar manner (Jämsä-Jounela et al., 2003). The principle differences compared with the mathematic models of single cells in series are that, in a double cell, both pulp levels are controlled by manipulating a control valve in the second cell outflow, as can be seen from Fig. 2. The cells are physically on the same level.

The pulp level in the second cell is measured and compared with the set point. This signal is used as input to a PI-controller. The output signal of the controller is the desired valve position as denoted by $\mathrm{u}_{1}$. The cells in a double cell are connected via a flange. The flange limits the maximum flow between the cells. The pressure difference in the cells is the only driving force for the flow, and depends on the density of the pulp.

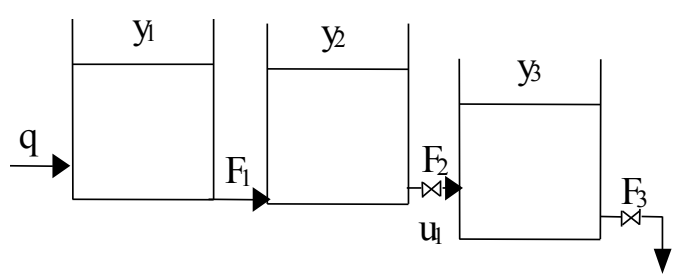

Fig. 2. Double flotation cell series

The velocity of outflow from the first cell can be derived using Bernoull's equation, resulting in

$$
v=\sqrt{2 g\left(y_{1}-y_{2}\right)}
$$

where $g=$ gravity, $\mathrm{y}_{1}=$ pulp level in the first cell, and $\mathrm{y}_{2}=$ pulp level in the second cell.

The volume flow across the flange can be calculated as

$$
F_{1}=v A_{\text {flange }}=\sqrt{2 g\left(y_{1}-y_{2}\right)} l_{l} h_{l}
$$

where $\mathrm{A}_{\text {flange }}=$ cross-sectional area of the flange, $\mathrm{l}_{1}=$ length of the flange, and $h_{1}=$ height of the flange.

The pressure drop due to flowing resistances is assumed to be negligible and can be ignored. The change of the pulp volume in the first cell with respect to time can be written as

$$
\frac{\partial V_{1}}{\partial t}=q-F=q-\sqrt{2 g\left(y_{1}-y_{2}\right)} l_{l} h_{l}
$$

The outflow of the second double cell is similar to that of a single cell, and the flow into the second cell is the outflow of the first. Therefore the mathematical model is

$$
\begin{aligned}
\frac{\partial V_{2}}{\partial t} & =F_{1}-F=\sqrt{2 g\left(y_{1}-y_{2}\right)} l_{l} h_{l} \\
& -K_{2} C_{v}\left(u_{1}\right) \sqrt{y_{2}-y_{3}+h_{1}}
\end{aligned}
$$

\subsection{Modelling the Outokumpu flotation cells}

Fig. 3 shows the cross-section of the flotation cells under study. The pulp level changes as a function of the cell volume. The change is linear from the bottom of the cell to the starting level of the launders and boosters, denoted by $\mathrm{H}_{\text {lowerpart }}$ in Fig. 3. The cross-section of the pulp subsequently decreases on moving upwards because the launders and 'boosters' reduce the volume of the cell.

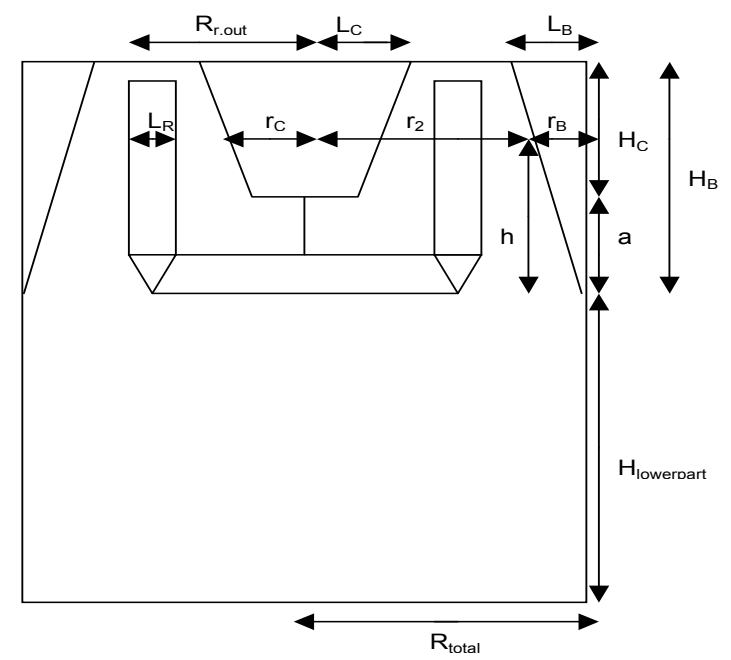

Fig. 3. Cross-section of a flotation cell of Outokumpu Mintec

Calculation of the pulp volume can be divided into two sections: the pulp level below and above the

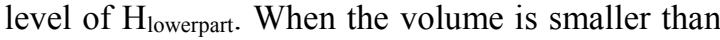
the volume of the cylinder's $\mathrm{H}_{\text {lowerpart, }}$ the pulp level is determined as

$$
h_{\text {tot }}=\frac{V}{\pi R_{\text {tot }}^{2}} \text {. }
$$

where $\mathrm{R}_{\mathrm{tot}}$ is the radius of the cell.

If the pulp volume is equal or greater than $\mathrm{H}_{\text {lowerpart, }}$ the volume is written as

$$
V=V_{\text {lower_part }}+V_{\text {upper_part }}(h)-V_{B}(h)-V_{R}(h)
$$

where $\mathrm{V}_{\text {lowerpart }}=$ volume of the cell below the level of $\mathrm{H}_{\text {lowerpart }}, \mathrm{V}_{\text {upperpart }}=$ volume of the cylinder above $\mathrm{H}_{\text {lowerpart, }} \mathrm{V}_{\mathrm{B}}=$ volume of the boosters, and $\mathrm{V}_{\mathrm{R}}=$ volume of the launders.

A level variable, the zero point of which is equal to $\mathrm{H}_{\text {lowerpart }}$ is denoted by $\mathrm{h}$. The volumes of the launder and booster are obtained by geometric relations, and substituting them in Eq. 12 results in 


$$
\begin{aligned}
& h^{3}\left(-\frac{\pi}{3} K_{B}^{2}\right)+h^{2}\left(\pi K_{B} R_{\text {total }}\right) \\
& +h\left(\pi\left(K_{R}-R_{\text {total }}^{2}\right)\right)+\left(V-V_{\text {lowerpart }}\right)=0
\end{aligned}
$$

where $\mathrm{K}_{\mathrm{B}}=$ constant coefficient of the booster dynamics and $\mathrm{K}_{\mathrm{R}}=$ constant coefficient of the launder dynamics.

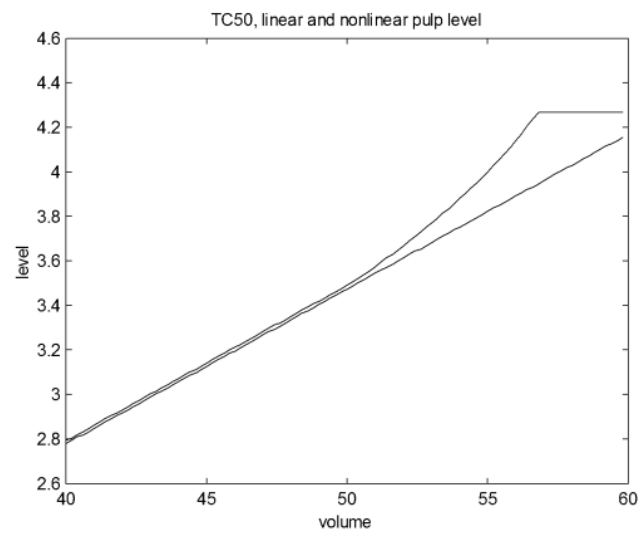

Fig. 4. Pulp level as a function of pulp volume

The third order equation has a solution in $\left[\mathrm{H}_{\text {lowerpar }}\right.$ $\left.\mathrm{H}_{\text {total }}\right]$, where $\mathrm{H}_{\text {total }}$ is the total height of the cell. $\mathrm{K}_{\mathrm{B}}$, $\mathrm{K}_{\mathrm{R}}$ and $\mathrm{V}_{\text {lowerpart }}$ are constants and specific for each cell size. The total level of pulp can be determined by summarizing $\mathrm{h}$ and $\mathrm{H}_{\text {lowerpart. }}$.

The effect of pulp level non-linearity can be seen in Fig. 4, in which the pulp level is presented in ideal tank conditions as a function of the pulp volume. The cell type is TC-50, the maximum volume of which is $50 \mathrm{~m}^{3}$.

\subsection{Valve sizing and characteristic curve of the valves}

Valve sizing is based on the $\mathrm{C}_{\mathrm{v}}$ value, which is calculated according to the ISA standard as follows:

$$
C_{v}=1.17 Q \cdot \sqrt{\frac{\rho}{\Delta p}}
$$

Where

$\mathrm{Q}$ is the flow rate, $\mathrm{m}^{3} / \mathrm{h}, \mathrm{C}_{\mathrm{v}}$ the valve capacity coefficient, $\rho$ the pulp density, $\mathrm{kg} / \mathrm{m}^{3}$, and $\Delta \mathrm{p}$ the pressure difference over the valve.

The flow rate $\left(\mathrm{m}^{3} / \mathrm{h}\right)$ through the cell is calculated as

$$
Q=1.2 \frac{V_{\text {cell }}}{\tau / 60}
$$

where $V_{\text {cell }}$ is the cell volume $\left(\mathrm{m}^{3}\right)$ and $\tau$ is the pulp retention time in the cell.
The valves in the models are sized for a flow which has a retention time of $1.5 \mathrm{~min}$ in one cell. The flow rate to the first cell is also calculated using this retention time value.

Characteristic curves of the control valves are produced by Larox Flowsys and were used in the Simulink models in order to cause realistic and nonlinear behaviour for the valves.

\section{Control strategies}

The different control strategies are discussed and described in the following sections. These strategies are selected because they can be used with basic PIcontrollers and without any additional instrumentation. Traditionally in flotation cell series there is only one flow measurement in the beginning of the series and level PI-controllers in every cell.

\subsection{Feed forward controller}

A flow feed-forward controller monitors disturbances in the inflow to the first cell and uses proportional action to close or open the valves of the cell in order to compensate for disturbances. Compensation is linearly dependent on the difference between the current inflow and the normal inflow. The measurement signal is filtered in order to prevent the feed-forward control from reacting to random variation in the flow. However, this kind of controller does not provide any extra performance improvement in the event of disturbances occurring somewhere else in the cell series. The model of the feed-forward controller is shown in Fig.5.

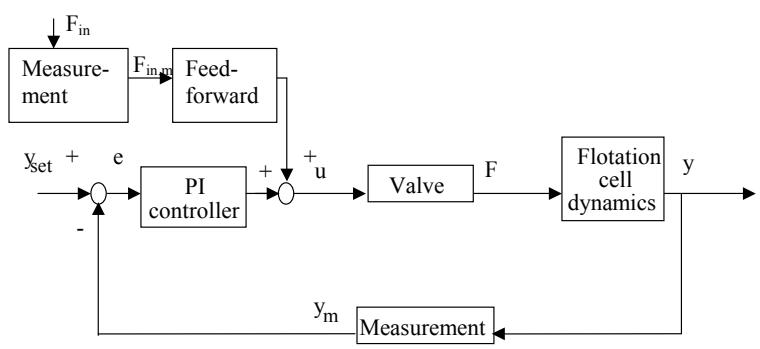

Fig. 5. Control diagram of feed-forward controller.

\subsection{Decoupling controller}

A decoupling controller is based on differential equations (1)-(3). The purpose of the decoupling controller is to eliminate the crosswise effects of control loops, and hence the stability of a single control circuit depends only on its own stability features. The basic model of the decoupling controller is shown in Fig. 6. 


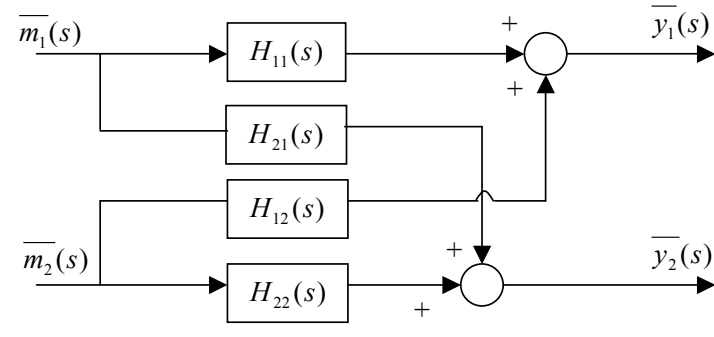

Fig. 6. Control diagram of a basic decoupling controller.

The mathematical criterion to be fulfilled for decoupling a tank $i$ will be

$$
\Delta F_{\text {iin }}-\Delta F_{\text {iout }}=0
$$

where $\Delta F_{\text {iin }}$ is a change of inflow to tank $i$. Using the valve functions from Eqs. (1)-(3) the equation can be written as follows

$$
F_{i}=K_{i} C_{v i} u_{i} \sqrt{\left(\Delta h_{i}\right)}
$$

where $\Delta h_{i}$ is the level difference over the valve. Substituting in Eq. (4), it becomes

$$
\begin{aligned}
& K_{i-1} C_{i-1}\left(u_{i-1}+\Delta u_{i-1}\right) \sqrt{\left(\Delta h_{i-1}+\Delta\left(\Delta h_{i-1}\right)\right)} \\
& -K_{i} C_{i}\left(u_{i}+\Delta u_{i}\right) \sqrt{\left(\Delta h_{i}+\Delta\left(\Delta h_{i}\right)\right)}=0
\end{aligned}
$$

Solving this equation for the change in the control signal gives

$$
\begin{aligned}
& \Delta u_{i}=\left(K_{i-1} C_{i-1} / K_{i} C_{i}\right) u_{i-1}^{\prime} \sqrt{\left(\Delta h_{i-1}^{\prime}\right) /\left(\Delta h_{i}^{\prime}\right)}-u_{i} \\
& =f\left(u_{i-1}^{\prime}, \Delta h_{i-1}^{\prime}, \Delta h_{i}^{\prime}\right)
\end{aligned}
$$

Eventually, the control signal for a tank $i$ becomes

$$
u_{i}=u_{P I}+f\left(u_{i-1}, \Delta h_{i-1}, \Delta h_{i}\right)
$$

where $u_{P I}$ is the control signal from a PI-controller. In order to handle the variations from the inflow, the feed forward is attached to the first tank.

\subsection{Multivariable controller similar to Floatstar ${ }^{\mathrm{TM}}$}

A multivariable controller (Schubert et al., 1995) controls the total inventory of material in the upstream tanks. In this control strategy, controlling a valve is influenced not only by the difference between a set point and the measured level in the tank, but also the differences between set points and the measured levels in all the tanks in upstream. These variables are summed and fed to the PI-controller of the cell. Furthermore, the variables are scaled by a suitable factor depending on the valve size, position and process.

In this strategy each control valve can be regarded as a sluice gate of a dam. When a damned inventory is too high in upstream, the valves are opened more than usual, even when there seems to be no need to take such an action on the basis of the levels in the neighbouring vessels. The control diagram is shown in Fig. 7.

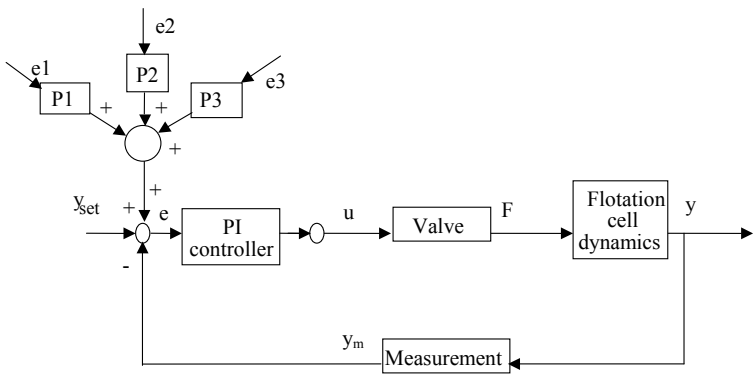

Fig. 7. Control diagram of a multivariable controller similar to Floatstar' ${ }^{\text {TM }}$ (tank 4).

\subsection{New multivariable controller}

When some disturbance occurs in tank, it has an effect to level in the previous tank in upstream. Previously described multivariable control does not take disturbances of this kind into account. Also strategy does not take into account disturbances arising from pulp feed. Therefore a flow feed forward has been added to the system and the difference between set point and measured level in next tank is also added to the controller of previous tank. The control diagram is shown in Fig 8.

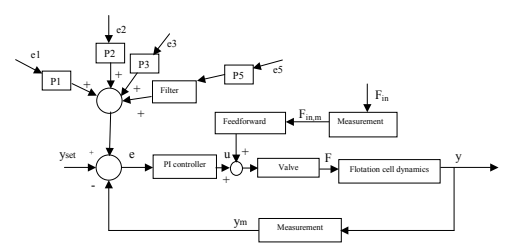

Fig. 8. The control diagram of MV controller (tank 4). 


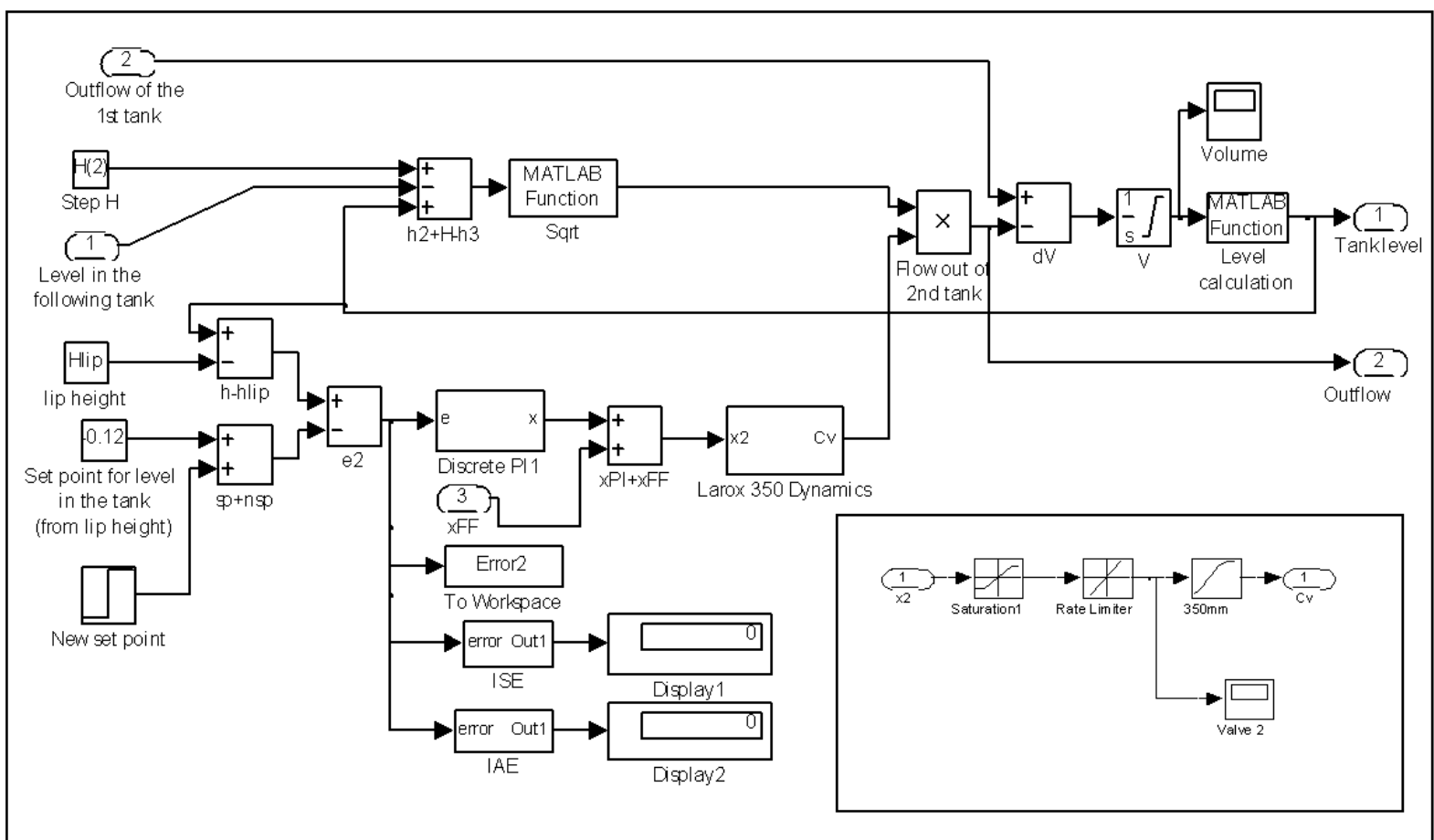

Fig. 9. Simulink model of the flow dynamics in a flotation cell

\section{Simulations}

In the simulations a configuration of six TC-50 cells in series was studied in accordance with the ideal tank assumption. Therefore the effects of boosters and launders were not considered. The valves were $100 \%$ oversized according to the ISA standard, and the retention time in each cell was $1.5 \mathrm{~min}$. Control strategies included conventional PI-controllers with feed-forward control, decoupling controller, a multivariable controller similar to Floatstar ${ }^{\mathrm{TM}}$ and a feed-forward multivariable controller. The simulation results of a $+3 \mathrm{~cm}$ change in the set points of the cell levels at times 100,150,200, 250, 300 and $350 \mathrm{~s}$ are presented in the following. Making $\pm 20 \%$ change in the feed to the first flotation cell was also simulated with different strategies. The set point of the cell level is lowest in the first cell, and the set point values increase on moving towards the last cell in the series, where the operating range of the level controller is smaller. The simulation schemes were constructed with Matlab 6.0.0 Simulink software. The Simulink model of the flow dynamics in the flotation cell is presented in Fig.9.

The controllers were tuned and compared using the following indices. The IAE index (integral of the absolute value of the error) integrates the absolute value of errors, and even-handedly weights all the deviations. ISE (integral of the square error) gives more weight to big deviations from the set point.

$$
I S E=\int_{t=t_{1}}^{t_{2}}\left(y(t)-y_{s p}(t)\right)^{2} d t
$$

$$
I A E=\int_{t=t_{1}}^{t_{2}}\left|y(t)-y_{s p}(t)\right| d t
$$

\section{Simulation results}

The simulations of the configurations of six TC-50 cells in series resulted in parameters for the PIcontrollers. Integration times in the traditional system with a feed-forward controller were between 15 and $50 \mathrm{~s}$ and proportional gains between 0.8 and 1.2. Because MIMO control strategies respond better to disturbances, the PI parameters were set faster. Integration times in all the PI-controllers were set to $15 \mathrm{~s}$ and gain to 1 . In the decoupling controller the PIparameters were between 15-50 $\mathrm{s}$ and 1-1.4 $\mathrm{s}$, correspondingly.

The responses of the feed-forward controller to disturbances in pulp feed and to set point changes are presented in Fig. 10. As can be seen, the $-20 \%$ change in pulp feed is affecting all the cell levels in the series. The set point changes in a cell also have undesirable effects on the adjacent cells. There is always a considerably large perturbation in the level of the next cell every time a set point change is made in the system.

The responses of the decoupling controller are illustrated in Fig 11. The decoupling controller is a MIMO controller, and it also takes into account the interactions between cells. As can been seen from the graphs, the decoupling controller effectively eliminates disturbances arising from changes in the 
pulp feed. Furthermore, set point changes in the cells do not affect to the other cells.

The responses of configurations in which a controller similar to Floatstar ${ }^{\mathrm{TM}}$ and the new multivariable controller are used are shown in Figs. 12 and 13. The new multivariable controller seems to be more robust than the other controller, especially during changes in pulp feed.
The IAE and ISE indices, which depict the performance of controllers, are shown in Tables 14. As was to be expected, the traditional SISO control with flow feed-forward had the poorest figures in all cases.
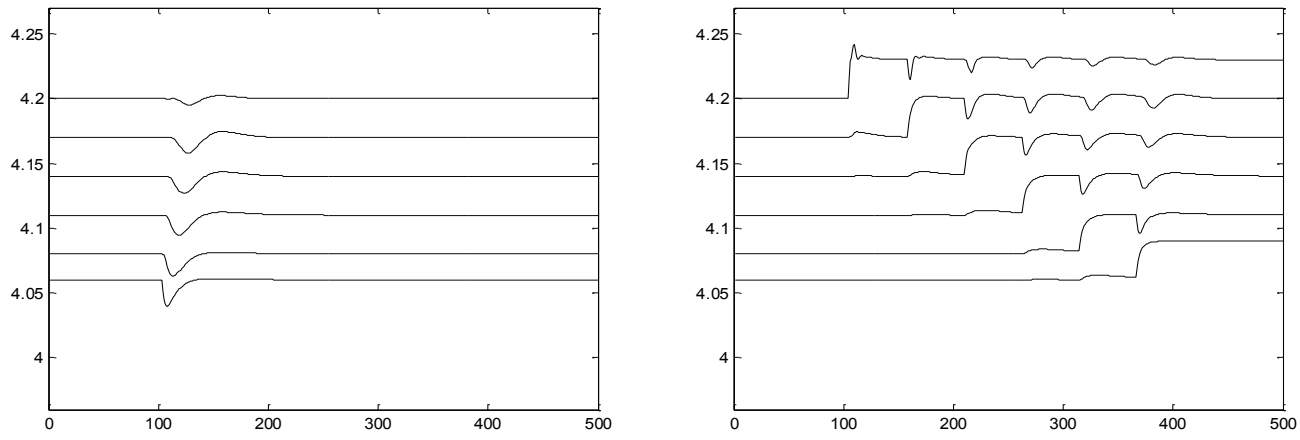

Fig. 10. Feed-forward controller. On the left the response to a $-20 \%$ change in pulp feed, and on the right the response to set point changes.
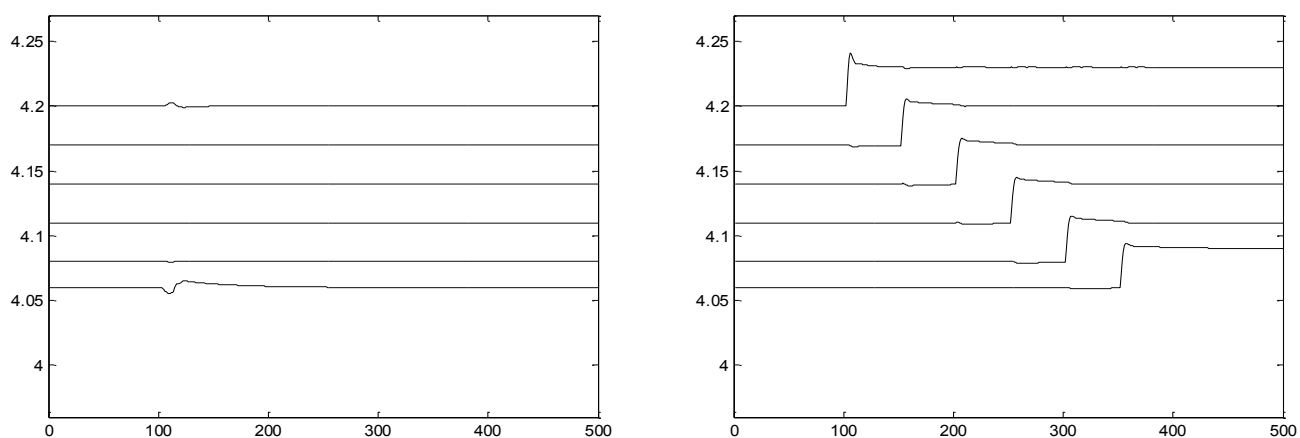

Fig. 11. Decoupling controller. On the left the response to a $-20 \%$ change in pulp feed, and on the right the response to set point changes.
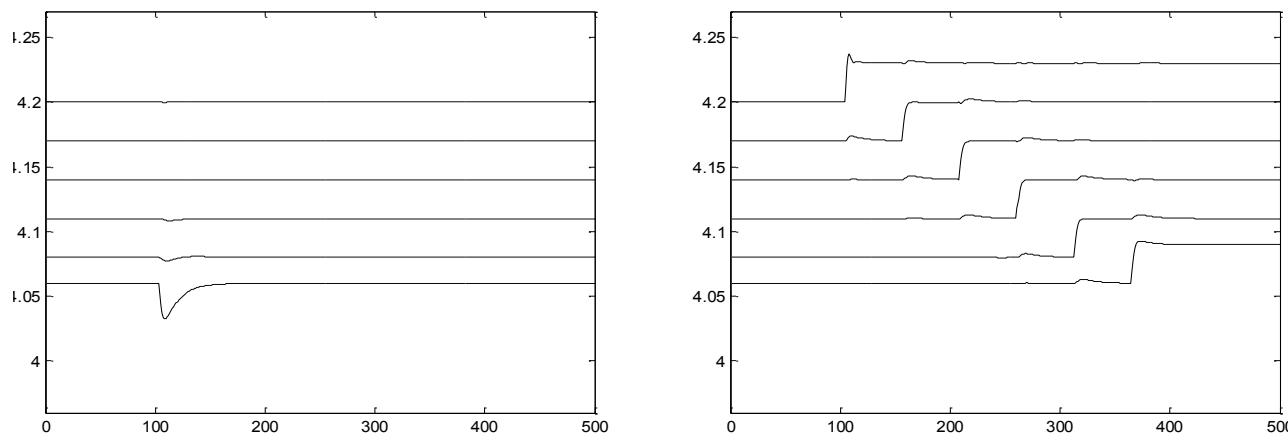

Fig. 12. Multivariable controller similar to Floatstar ${ }^{\mathrm{TM}}$. On the left the response to a $-20 \%$ change in pulp feed, and on the right the response to set point changes. 

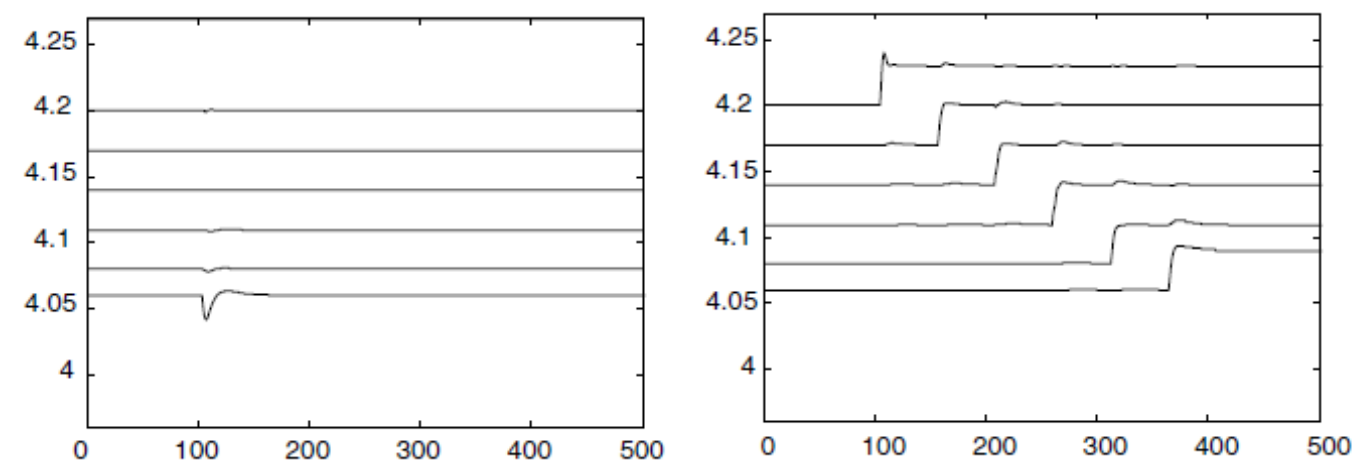

Fig. 13. New multivariable controller. On the left the response to a $-20 \%$ change in pulp feed, and on the right the response to set point changes.

Table 1. The performance indices for feed-forward controller

\begin{tabular}{lllllll}
\hline $\begin{array}{l}\text { Feed-forward } \\
\text { controller }\end{array}$ & ISE(+20\%) & IAE(+20\%) & ISE(-20\%) & IAE(-20\%) & ISE(s.p.c.) & IAE(s.p.c.) \\
\hline 1 & 3.10 & 348 & 3.7 & 325 & 2.7 & 298 \\
2 & 2.9 & 361 & 3.1 & 360 & 4.0 & 520 \\
3 & 2.7 & 371 & 3.3 & 391 & 5.0 & 712 \\
4 & 2.2 & 341 & 2.7 & 371 & 5.33 & 818 \\
5 & 2.0 & 322 & 2.4 & 361 & 6.5 & 970 \\
6 & 0.5 & 159 & 0.4 & 147 & 3.7 & 604 \\
\hline
\end{tabular}

Table 2. The performance indices for the decoupling controller

\begin{tabular}{lllllll}
\hline $\begin{array}{l}\text { decoupling } \\
\text { controller }\end{array}$ & ISE(+20\%) & IAE(+20\%) & ISE(-20\%) & IAE(-20\%) & ISE(s.p.c.) & IAE(s.p.c.) \\
\hline 1 & 1.10 & 327 & 0.7 & 263 & 2 & 220 \\
2 & 0.0008 & 10.2 & 0.0003 & 8.0 & 2.2 & 242 \\
3 & 0.0000008 & 0.3 & 0.00000004 & 0.1 & 2.2 & 241 \\
4 & 0.00000005 & 0.05 & 0.000000001 & 0.01 & 2.2 & 241 \\
5 & 0.0 & 1.2 & 0.000004 & 0.4 & 2.1 & 228 \\
6 & 0.04 & 29.5 & 0.019 & 19.5 & 2.1 & 179 \\
\hline
\end{tabular}

Table 3. The performance indices for the multivariable controller similar to Floatstar ${ }^{\mathrm{TM}}$

\begin{tabular}{lllllll}
\hline MV controller & ISE(+20\%) & IAE(+20\%) & ISE(-20\%) & IAE(-20\%) & ISE(s.p.c.) & IAE(s.p.c.) \\
\hline 1 & 7.81 & 499 & 9.02 & 527 & 2.2 & 202 \\
2 & 0.1 & 65.0 & 0.07 & 58.6 & 2.3 & 243 \\
3 & 0.03 & 25.2 & 0.03 & 26.5 & 2.3 & 248 \\
4 & 0.0001 & 2.2 & 0.00006 & 1.4 & 2.3 & 249 \\
5 & 0.0001 & 2.7 & 0.00008 & 1.5 & 2.3 & 245 \\
6 & 0.01 & 18.5 & 0.002 & 7.8 & 1.7 & 151 \\
\hline
\end{tabular}

Table 4. The performance indices for the new multivariable controller

\begin{tabular}{lllllll}
\hline new MV controller & ISE(+20\%) & IAE (+20\%) & ISE(-20\%) & IAE(-20\%) & ISE(s.p.c.) & IAE(s.p.c.) \\
\hline 1 & 1.79 & 216 & 2.1 & 231 & 2.2 & 204 \\
2 & 0.03 & 30.7 & 0.02 & 27.4 & 2.2 & 202 \\
3 & 0.007 & 12.3 & 0.007 & 13.2 & 2.2 & 211 \\
4 & 0.0001 & 1.1 & 0.00009 & 1.7 & 2.2 & 211 \\
5 & 0.0009 & 4.3 & 0.0005 & 3.5 & 2.2 & 212 \\
6 & 0.005 & 8.1 & 0.003 & 6.9 & 1.9 & 149 \\
\hline
\end{tabular}




\section{Conclusions}

All the simulated configurations were successfully tuned. It is noticeable that the classical SISO strategy with feed-forward controller cannot even approach the performances of the MIMO controllers. This is due to high interactions between the control loops, which SISO systems cannot take into account.

The differences between different MIMO systems are somewhat smaller. All the controllers performed robustly to disturbances in pulp feed and to set point changes. The decoupling controller had the best IAE and IDE indices. However, the decoupling controller is sensitive to model uncertainties (Skogestad and Postelwaite, 1996). This also means that process changes can strongly degrade the control performance.

\section{References}

Andersen, R., GRonli, B., Olsen, T., Kaggernd, I., RAmslo, K., Sanvik, K., 1979. An optimal control system of the rougher flotation at the Folldal Verk concentrator, Norway. In: Proceedings of the 13th International Mineral Processing Congress. New York, USA, pp. 1517-1540.

Hammoude, A., Smith, H., 1981. Experiments with self-tuning control of flotation. In: Proceedings of the 3rd IFAC Symposium on Automation in Mining, Mineral and Metal Processing. Oxford, UK, pp. 213-218.

Jämsä-Jounela, S-L., Laurila, H., Karesvuori, J., Timperi, J., 2001. Evaluation of the future automation trends in control and fault diagnostics - a case study in flotation plant. In: 10th IFAC Symposium on Automation in Mining, Mineral and Metal Processing.

Jämsä-Jounela, S.-L., Dietrich, M., Halmevaara, K., Tiili, O., 2003. Control of pupl level in flotation cells. Control Engineering Practise, 73-81.

Koivo, H., Cojocariu, R., 1997. An optimal control for a flotation circuit. Automatica 13 (1), 37-45.

Niemi, A., Maijanen, J., Nihtilä, M., 1974. Singular optimal feed forward control of flotation. In: IFAC/IFORS Symposium on Optimization Methods - Applied Aspects. Varna, Bulgaria, pp277-283.

Schubert, J.H., Henning, R.G.D., Hulbert, D., Craig, I.K., 1995. Flotation control - a multivariable stabilizer. In: XIXth IMPC, San Fransisco, vol. 3, pp.237-241.

Skogestad, S., Postelwaite, I., 1996. Multivariable Feedback control: Analysis and design. John Wiley \& Sons.

Stenlund, B., Medvedev, A., 2000. Level control of cascade coupled flotation tanks. Future trends in Automation in Mineral and Metal Processing. In: Jämsä-Jounela, S.-L., Vapaavuori, E. (Eds.), IFAC Workshop 2000, Helsinki, Finland, pp. 194-199.
Zargiza, R., Herbst, J.A., 1987. A model based feed forward control scheme for flotation plants. In: 116th AIME annual meeting. Denver, CO, USA, pp. 23-27. 